amenable to blocking of the local nerves. ${ }^{7}$ Rectal indomethacin with its systemic effect was shown to be a more efficient analgesic agent, providing a broader degree of pain control. On all the variables we measured rectal indomethacin had a stronger analgesic effect than cryoanalgesia. The combination of rectal indomethacin and cryoanalgesia produced an additive effect. The ease of administration of rectal indomethacin, with its simplicity in use, its absence of noted side effects, and its low cost, has much to commend it in thoracic surgery. Its potential benefit in other branches of surgery is apparent. We should like to add a cautionary note, however, concerning the concurrent administration of subcutaneous heparin: before conducting this trial we saw several cases of persistent bleeding after surgery, but no such cases occurred after we stopped the routine use of subcutaneous heparin.

Of the available methods for effectively controlling pain after thoracotomy, the epidural route, although effective, has much against it in terms of possible complications and the need for specialised staff, while a cryoprobe is simple to use provided that the equipment is available. Similarly, continuous intravenous infusions of opiate are effective ${ }^{2}{ }^{3}$ but require an infusion pump and trained medical staff to start and supervise treatment, while intramuscular injection of opiate, in sufficient dosage to produce satisfactory analgesia, may produce appreciable respiratory depression. Indomethacin administered rectally has none of these drawbacks. We recommend its use after thoracotomy, both alone and as an adjuvant to other analgesic regimens. We found it singularly efficacious in reducing pain on movement, and it could thus make a considerable contribution to effective physiotherapy and earlier mobilisation.

It is difficult to produce useful objective data on the influence of analgesics on changes in respiratory function after thoracotomy. We were impressed with the way in which peak flow values mirrored the other variables and provided useful information.
We conclude that rectal indomethacin provides good, safe, simply administered analgesia after thoracotomy and has an additive effect when used as an adjuvant to conventional analgesia such as cryoanalgesia.

We thank Mr I K R McMillan for allowing us access to his patients and $\mathrm{Dr} M$ Campbell for performing the statistical analysis of our results.

\section{References}

${ }^{1}$ Parkhouse J, Lambrechts $\mathbb{W}$, Simpson BRJ. The incidence of postoperative pain. Br 7 Anaesth $1961 ; 33: 345-53$.

2 Orr IA, Keenan DJM, Dundee JW. Improved pain relief after thoracotomy: use of cryoprobe and morphine infusion. $\mathrm{Br} M e d \mathcal{F} 1981 ; \mathbf{2 8 3}$ : 945-8.

${ }^{3}$ Nayman J. Measurement and control of post-operative pain. Ann R Coll Surg Engl 1979;61:419-26.

4 Rutter PC, Murphy F, Dudley HAF. Morphine: controlled trial of different methods of administration of post-operative pain relief. $\mathrm{Br} \mathrm{Med} \mathcal{Y}$ $1980 ; 280: 12-3$.

5 Simpson BRJ, Parkhouse J, Marshall R, Lambrechts W. Extradural analgesia and the prevention of post-operative respiratory complications. Br F Anaesth 1961;33:628-41.

${ }^{6}$ Bromage PR. Extradural analgesia for pain relief. Br $\mathcal{F}$ Anaesth 1967; 39:721-9.

7 Nelson KM, Vincent RG, Bourke RS, et al. Intra-operative intercostal nerve freezing to prevent post-thoracotomy pain. Ann Thorac Surg $1974 ; 18: 280-5$.

${ }^{8}$ Katz J, Nelson W, Forest R, Bruce DL. Cryoanalgesia for post-thoracotomy pain. Lancet $1980 ; \mathrm{i}: 512-3$.

${ }^{9}$ Maiwand O, Makey AR. Cryoanalgesia for relief of pain after thoracotomy. Br Med F 1981 ;282:1749-50.

${ }^{10}$ Loan WB, Dundee JW. The clinical assessment of pain. Practitioner 1967;198:759-68.

${ }^{11}$ Huskisson EC. Measurement of pain. Lancet 1974;ii:1127-31.

12 Aitken RCB. A growing edge of measurement of feelings. Proceedings of the Royal Society of Medicine 1969;62:989-93.

\title{
Sex hormones and skin collagen content in postmenopausal women
}

\author{
M BRINCAT, C F MONIZ, J W W STUDD, A J DARBY, A MAGOS, D COOPER
}

\begin{abstract}
Skin biopsy specimens were taken from 29 postmenopausal women who had not been given hormone replacement therapy and from 26 women who had been treated with oestrogen and testosterone implants for two to 10 years. The mean hydroxyproline content and therefore the mean collagen content in the skin was found to be $48 \%$ greater in the treated than the untreated women,
\end{abstract}

\footnotetext{
Dulwich Menopause Clinic, Department of Obstetrics and Gynaecology, and Department of Pathology, King's College Hospital Medical School, London SE5

$M$ BRINCAT, MRCS, LRCP, research registrar C F MONIZ, MB, MRCPATH, consultant J W W STUDD, MD, MRCOG, consultant A J DARBY, MRCPATH, consultant

A MAGOS, $\mathrm{MB}, \mathrm{BCH}$, research registrar

D COOPER, MSC, PHD, senior programmer

Correspondence to: Dr M Brincat, Obstetric Unit, Dulwich Hospital, London SE22 8PT.
}

who were matched for age. This difference was significant $(\mathbf{p}<\mathbf{0 . 0 1})$.

The implication of this finding is that oestrogen or testosterone, or both, prevents the decrease in skin collagen content that occurs with aging and protects skin in the same way as it protects bone in postmenopausal women.

\section{Introduction}

Oestrogen treatment is gaining widespread use as its ability to relieve symptoms of the climacteric and prevent osteoporosis become better appreciated. ${ }^{2}$ Studies on oestrogens and bone have not been matched with work on the skin, ${ }^{3}$ although the biochemistry of the collagen matrix of bone is basically similar to that of the collagen in skin. There is only indirect evidence of the effects of oestrogens and testosterone on the skin. Shuster et al showed a linear decrease in skin collagen content of about $1 \%$ per year through adult life, with the skin collagen being less in women than in men. ${ }^{4-8}$ This difference between the sexes was attributed to testosterone. They also showed that 
skin thickness, which is closely associated to skin collagen content, showed a significant sharp decrease in women after the fifth decade.

An association has been made between thin skin and osteoporosis $^{6-8}$ but never in connection with the climacteric. McConkey et al believed that "transparent skin" is a consequence of a change in the connective tissues and that a similar change may occur in bone. ${ }^{7}$ As there are both oestrogen and androgen receptors on fibroblasts in the $\operatorname{skin}^{6} 910$ we investigated the effects of oestradiol and testosterone on the skin of postmenopausal women.

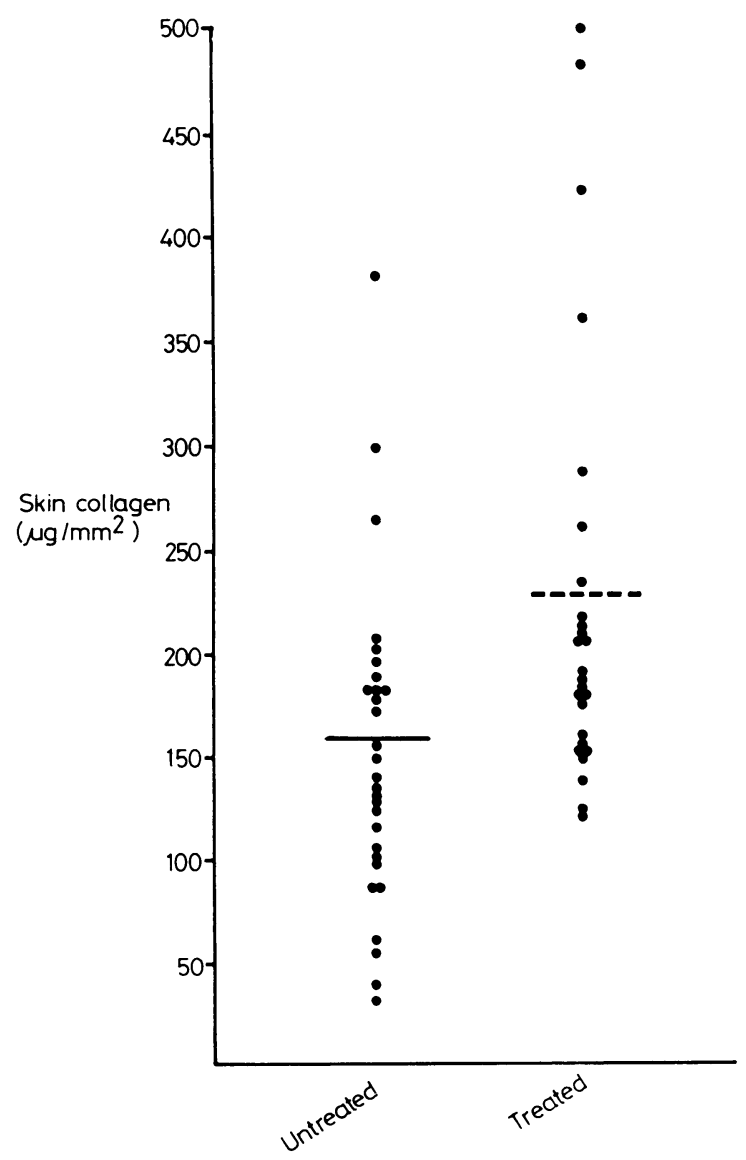

Total collagen content in $3 \mathrm{~mm}$ biopsy specimens obtained from postmenopausal women, either untreated or receiving hormone treatment. Horizontal lines indicate means.

\section{Patients, methods, and results}

We selected as controls 29 untreated postmenopausal volunteers attending the Dulwich Hospital menopause clinic. They were compared with a group of women of similar age who had been receiving implants of oestradiol $50 \mathrm{mg}$ and testosterone $100 \mathrm{mg}$ for two to 10 years. $^{2}$ In addition, norethisterone $5 \mathrm{mg}$ for seven days of each cycle was given to the 11 women who had a uterus to prevent endometrial hyperplasia. ${ }^{11}$ The mean age of the treated women was 50.3 years (range 35-62) with a mean menopausal age of 6.35 years (range 2-13) and a mean duration of treatment of $4 \cdot 3$ years (range 2-7). The untreated women had a mean age of $49 \cdot 1$ years (range 33-60) and a mean menopausal age of 3.5 years (range 3 months- 12 years).

Punch biopsy specimens of skin, $3 \mathrm{~mm}$ in diameter, were taken from the right thigh $5 \mathrm{~cm}$ below the greater trochanter. The hydroxyproline content was determined by Woessner's method ${ }^{12}$ and the collagen content calculated as described by Neuman and Logan. ${ }^{13}$
The result was expressed in $\mu \mathrm{g} / \mathrm{mm}^{2}$ skin surface. This is the most satisfactory way of expressing the skin collagen content. ${ }^{14}$ The results were analysed using Student's $t$ test.

The mean (SD) skin collagen content was $156.21(78.53) \mu \mathrm{g} / \mathrm{mm}^{2}$ in the 29 untreated patients and $230.89(104.35) \mu \mathrm{g} / \mathrm{mm}^{2}$ in the 26 patients receiving hormone replacement treatment; this $47.8 \%$ difference between the two groups was significant $(p<0 \cdot 01)$.

\section{Discussion}

Our results for the untreated women agree with previously reported values for forearm skin of women in the same age range $\mathrm{s}^{51415}$ and show that patients treated with oestradiol and testosterone have a skin collagen content $48 \%$ higher than that of untreated controls of similar age. This finding supports the clinical belief that the skin of postmenopausal women receiving hormone replacement looks less aged.

Though the evidence currently available seems to indicate that testosterone is responsible for the increase in collagen in treated women, ${ }^{5} 7$ we believe that oestrogen must contribute as plasma testosterone concentrations do not decrease after the menopause. ${ }^{16}$ The withdrawal of oestrogen at the menopause is the factor that leads to the accelerated skin changes ${ }^{5}$ and to osteoporosis in women. ${ }^{1}$ It is the lack of collagen and change in elasticity that contribute to the characteristic appearance of old skin. Our results, however, have more than just cosmetic implications as fibroblasts and other closely related cells occur in many sites other than the skin. It seems that skin changes after the menopause, like bone changes, take time to develop in measurable proportions. Similarly, it might take several months or years for the response to sex hormones to be noticeable.

\section{References}

${ }^{1}$ Crilly RG, Francis RM, Nordin BEC. Steroid hormones, ageing and bone. Clin Endocrinol Metab 1981;10:115-39.

${ }^{2}$ Studd JWW, Chakravati SK, Oram DH. The climacteric. Clin Obstet Gynaecol 1977;4:3-29.

${ }^{3}$ Shahrad P, Marks R. Skin changes at the time of the climacteric. Clin Obstet Gynaecol 1977;4:207-26.

4 Shuster S, Black MM, Bottoms E. Skin collagen and thickness in women with hirsuites. Br Med $\mathcal{F} 1970$; iv :722.

${ }^{5}$ Shuster S, Black MM, McVitie E. The influence of age and sex on skin thickness, skin collagen and density. Brf Dermatol 1975 ;93:639-43.

' Black MM, Shuster S, Bottoms E. Osteoporosis, skin collagen and androgen. Br Med $\mathcal{F} 1970$;iv:773-4.

${ }^{7}$ McConkey B, Walton KW, Carney SA, Lawrence JC, Ricketts CR. Significance of occurrence of transparent skin. A study of histological characteristics and biosynthesis of dermal collagen. Ann Rheum Dis $1967 ; 26: 219-25$.

${ }^{8}$ Stevenson CJ, Bottoms E, Shuster S. Skin collagen in oesteogenesis imperfecta. Lancet $1970 ; \mathrm{i}: 860-1$.

${ }^{9}$ Punnonen R. Effect of castration and peroral therapy on the skin. Acta Obstet Gynecol Scand [Suppl] 1973;21:1-44.

${ }^{10}$ Ozasa $\mathrm{H}$, Tominagant, Nishimura T, Takeda T. Evidence of receptor dependent response to dishydrotestosterone in cultured fibroblasts. Endokrinologie $1981 ; 77: 129-36$.

11 Thom MH, White PJ, Williams RM, et al. Prevention and treatment of endometrial disease in climacteric women receiving oestrogen therapy. Lancet 1979 ;ii :455-7.

${ }^{12}$ Woessner JE Jr. The determination of hydroxyproline in tissue and protein samples containing small proportions of this aminoacid. Arch Biochem Biophys $1961 ; 93: 440-7$.

${ }_{13}$ Neuman RE, Logan MA. The determination of collagen and elastin in tissues. F Biol Chem 1950;186:549-56.

${ }^{14}$ Shuster S, Bottoms E. Senile degeneration of skin collagen. Clin Sci $1963 ; 25: 487-91$.

${ }_{15}$ Arho $P$. Skin thickness and collagen content in some endocrine connective tissue and skin diseases. Acta Derm Venereol [Suppl] (Stockh) 1972;69: $1-48$.

${ }^{16}$ Chakravati S, Collins WP, Forecast JD, Newton JR, Oram DH, Studd JWW. Hormonal profiles after the menopause. $\mathrm{Br} \operatorname{Med} \mathcal{F} 1976$;ii :784-6.

(Accepted 15 August 1983) 